$\overline{\text { 論交 }}$

\title{
Nagel 氏アノマロスコープによる色覚検査補遺
}

$$
\text { 正会員市川宏* }
$$

\section{Invetsigations on Rayleigh equations, and the use of Nagel's anomaloscope.}

By Hiroshi Ichikawa (Member)

(Department of ophthalmology, Tokyo Railway Hospital.)

\begin{abstract}
In the hope to find out a method which could depict the normal range of an anomaloscope independently from the characteristics of each instrument, a theoretical formula was obtained and a construction was made. The same method also enabled the construction of the equivalent regions of protanomaly and deuteranomaly. This result conversely proved that the anomal quotient held good independently from the choice of the instrument and light sourse. Thus the normal range and the locus of the equivalent regions of protanomaly and deuteranomaly could be depicted on the graph of the relation between the anomal qnotient (A.Q.) and the scale of the color-mixing screw. These graphs were valuable when use was made of a new anomaloscope. In addition description was made on the procedure of the test of color vision with an anomaloscope and on some required precautions.
\end{abstract}

\section{1. 緒 言}

1929年，J国眼科学会に扮いて Engelking 法，色觉

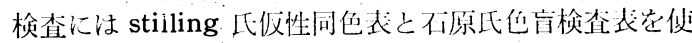
用すること，更に䊑密な診断のために注 Nagel氏ア.ノ、 ロスコープを用うべきであることを提县している。この

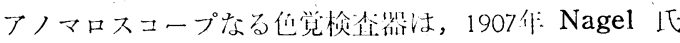
によって作られた一種の Colorimeter で，小さい視野 の上半分に $670 \mathrm{~m} \mu$ の赤色光之 $536 \mathrm{~m} \mu$ の綠任光の㴀合 光線が，下半分に $589 \mathrm{~m} \mu$ の黄仙光が現われるようにな っていてこの赤と緑の混合光線と黄の単色光との間の

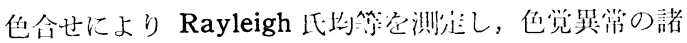
型を正確に判起するのが本器の役山である。同器の構造 を加藤氏の著書分ら借りて第1四に示与。今日普及して

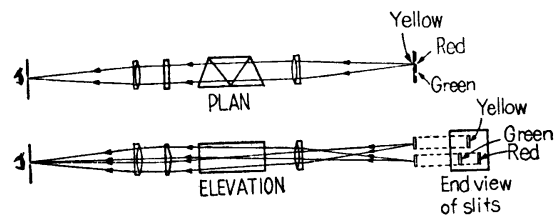

第 1 図 Nagel 氏 Anomaloskop の構造

いるアノマロスコープII型は，移動据子觉動かして接眼 筒内の視野を分散スペクトルム上で水平に動かすをとに より，可視大ペクトルム全域に抢よぶ混色試験を可能に したものである。この場合监色スリットから $589 \mathrm{~m} \mu$ の

* 東京鉄道病院眼科
ナトリウム光が射入する位置に移動颃子を固定寸れば， 混色网スリットから汢Ｉ型の埸合とは波長に多少のズレ はあるが赤上線の二種の単色光による混合光線が得ら れ，I型と间様の手段で色觉検查が可能となるのであ る.

アノマロスコープはこのようにして色觉異霄の部断を 簡単，かつ正確に可能ならしるるものであるが，その操 作はかならずしも容易でなく，米国の学者すらナノマ口 スコーブを正しく使用している眼科医注掼く少いとい。 ていることからも本器の普及状況が想像される。厂ノマ ロスコープがこのように馴染みの薄いものである理由を 私は, 本器の操作上に要求される多くのわづらわしさの 他に，機械の個性そのものに原因があると考えている。 アノマロスコープに慣れない人は，應多成書に記載され ているような黄赤均等值や黄綠垤等值が異常者に求めら れないと苦情をいい，更に困ることは，使用しているア ノマロスコープでレーレー均等を求めたところ，ある例 で法正常レーレー值よりも混色ネジ度目が，例えば 6 度 目ズレているが，これを正常範囲にあるとみてよいかど うかの質閒をうける場合が稀でないことである。このよ うな疑䦌は型が普及寸るようになってとくにいらじる しくなったように思われる。关北は使用しているアノマ ロスコープの性質をよく理解しないことにもよるが，正 常レーレーの混色不ヂ度目 $(\mathrm{Rn})$ の位置が60（あるいは 40)になくてこれよりもいくらかズレている牊, Engelking や Trendelenburg が述べているような正常範囲 
をとのまま使ってよいものか. あるいはどう修正すべき ものかわからないし，色弱均等の部位が当然ズレている と解っても，どの位置にズレているかがわからないから であると思う。（Nagel氏アノマロスコープは初期のも のは正常レーレー（Rn）が60となるように作られたの が, その後 $\mathrm{Rn}=40$ に改められ, 今日のアノマロスコー プは多少のズレはあってもすべて $\mathrm{Rn}=40$ になるように 作られている。）私は国鉄に扒いてほとえど全国の病院 にアノマロスコープが俌えられていながら，公分に活月 されていない現状爸これらの理由に基くと考元ている。 この敌に. 使用しているアノマロスコープについて止潘 レーレー值さえ求めれば，珢常均等の範囲や绝弱者の均 等部位を知ることが出来るようになれば，アノマロスコ 一プは一層色敩検查に使用されて, 災害医学的色临研究 に奇与する面が大であるうと考え，上記の目的に沿うよ うな理論計算を試みた。

\section{2. 理論計算とその応用}

アノマロスコープの混色試験に際して操作される2種

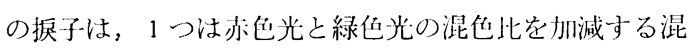
色ネヂであり, 他の1つは単色光の光量を增減する単色 ネヂである。泚任ネヂによって開閉される1対の細隙の 巾の和は常に一定であって，例えば混任ネジ度目が $\mathrm{a} の$ 時は混色に用いられる 2 種の単色光のうら短波長供の光 線の細腺门が a 単位，長波长側の光線の細隙巾が73- a 単位となり，この時被検者の眼に入る 2 単色光の混合比

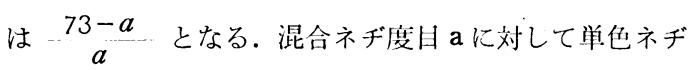
度目 $\mathrm{c}$ で㘬等したとすれば。 $\frac{73-a}{a}$ の比の混合色光と c 単位の単色光とが均等したことを意味している.一般 に均等の成り立つ混色齐ヂ度目は 1 つの值と限らず, 均 等值に巾がある場合が多い，この均等の成り立つ範四を 均等範囲といい，均等範四の公いものはスペクトルムの ナトリウム輝線の波垓部位における弁色能の焽いことを 示している. また被検者の $\frac{73-a}{a}$ の比が正常者の值と異 った值をもつ場合色弱と䛦断される。Tfrendelenburg （1929）は異常者の $\frac{73-a^{\prime}}{a^{\prime}}$ と正常者の $\frac{73-a}{a}$-との比 はアノマロスコープの機械に関係なく一定であるとし て, $\frac{73-a^{\prime}}{a}: \frac{73-a}{a}$ を Anomalquotient (異常比)

（以下A.Q.と略す）とし，色弱の程度を測る尺度にす ることを捉唱している。この論文において私が理論式を 作ろうとした意図は，任意の被検者について，あるアノ マロスロープで得られた均等值と均等範囲が，異った正 常レーレー均等值をもつ他のフノマロスロープで如何な る均等値と均等範囲をもつかを知ることの出来る図表を
式によって誘導しようとする点にある。

今アノマロスロープの均等検查における混色ネヂ度目 ( $a$ )を横座標, 単色ネヂ度目 $(c)$ を就座標とすると, 色 盲の均等值の軌跡は，

$$
a L+(73-a) K=c M
$$

で与えられる。 $L, M, K$ は用いた器械における $670 \mathrm{~m} \mu$, $589 \mathrm{~m} \mu, 536 \mathrm{~m} \mu$ の主钼的明度を示す. そこで 3 色光の 各一篮位量の与天る主钼的明度比党 $l: m: k$, 用いた器 械における 3 们光のエネルギー量の比空 $p: q: r$ 上する と(1)式泣,

$$
a l p+(73-a) k r=c m q
$$

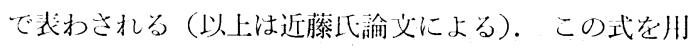
いて, アノマロスコープの器械が变った場余に正常均等 籁囲の账界を示す混他ネジ度けが如们に变容するかの理 論式を䆃くことを試みた。

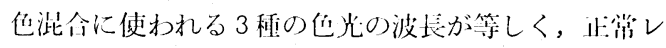
ーレー均等值の異る2つのアノマロスコープ，即ち標準 アノマロスコープA $(p, q, r)$ と, 検查対象のアノマ

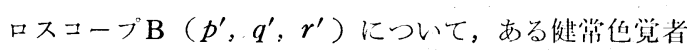
$\left(l_{1}, m_{1}, k_{1}\right)$ がアノマロスコープ $\mathrm{A}$ で均等值 $\left(\alpha_{1}, c_{1}\right)$, アノマロスコープBで均等直 $\left(a_{2}, c_{2}\right)$ 定得ら机たとす

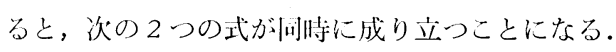

$$
\left.\begin{array}{ll}
a_{1} l_{1} p+\left(73-a_{1}\right) k_{1} r=c_{1} m_{1} q & \text { (anomalo. } \mathrm{A}) \\
a_{2} l_{1} p^{\prime}+\left(73-a_{2}\right) k_{1} r^{\prime}=c_{2} m_{1} q^{\prime} & \text { (anomalo. } \mathrm{B})
\end{array}\right\} \cdots
$$

この場合 $l: m: k$ は3 色光に刘子る主観的明度比であ るから，被検者個人の色感によって沈定されるもので， 器械に無閘係である。

(3)式から $l_{1} ， k_{1} ， m_{1}$ を消去すると，

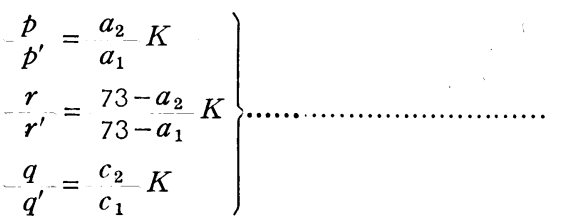

(4)式を満足する2つのアノマロスコープAと Bについ て, 某被検者 $\left(l_{2}: k_{2}: m_{2}\right)$ が均等試験をうけ, アノマ ロスコープAで $\left(a_{1}{ }^{\prime}, c_{1}{ }^{\prime}\right)$, アノマロスコープBで $\left(a_{2}{ }^{\prime}\right.$, $\left.c_{2}^{\prime}\right)$ の均等值を得たとすると，

$$
\left.\begin{array}{l}
a_{1}{ }^{\prime} l_{2} p+\left(73-a_{1}{ }^{\prime}\right) k_{2} r=c_{1}{ }^{\prime} m_{2} q \text { (anomalo. } \mathrm{A} \\
a_{2}{ }^{\prime} l_{2} p^{\prime}+\left(73-a_{2}{ }^{\prime}\right) k_{2} r^{\prime}=c_{2}{ }^{\prime} m_{2} q^{\prime} \text { (anomalo. } \mathrm{B}
\end{array}\right\} \cdots
$$

(5)式から

$$
\left.\begin{array}{l}
\frac{p}{p^{\prime}}=\frac{a_{2}{ }^{\prime}}{a_{1}{ }^{\prime}} K \\
\frac{r}{r^{\prime}}=73-a_{2}{ }^{\prime} \\
73-a_{1}{ }^{\prime} \\
\frac{q}{q^{\prime}}=\frac{c_{2}{ }^{\prime}}{c_{1}^{\prime}}-K^{\prime}
\end{array}\right\}
$$


(4)と(6)から

$$
\left.\begin{array}{rl}
a_{2}{ }^{\prime} & =\frac{a_{2}}{a_{1}} \cdot a_{1}{ }^{\prime} K \\
c_{2}^{\prime} & =\frac{c_{2}}{c_{1}} \cdot c_{1}{ }^{\prime} K \\
K^{\prime \prime} & =\frac{73}{\frac{a_{2}}{a_{1}} a_{1}{ }^{\prime}+\frac{73-a_{2}}{73-a_{1}}\left(73-a_{1}{ }^{\prime}\right)}
\end{array}\right\}
$$

(7)の式は $p, q, r$ 值が消去されているから，この式は 器械に関係なく成立することがわかる。正常レーレ一均 等値の既知の 2 つのノママロスコープを用いた場合，標 準のアノスロスコープ（A）におけるある均等值がアノ マロスコープ（B）で如何なる均等值となるかは，(7)の 式を用いることによって計算することが出来る.

以上述べた理論式が成立するためには，使用するア， マロスコープから得られる3つの色光の主辛波長が正し く同じであり，またてノマロスコープの正常レーレー值 Rn が60でも40でも，おのおのの条件の時の細淂から出 る波長域と主字波長の位置が常に一定であることが必要 である。しかし实際私達の用いるアノマロスコープは光 学上の陌から第 1 表および第 2 図の如く主幸波長およ び波長巾が細隙の開閉に伴って变化するし，また多くの

第 1 表 フノマロコープの Spelt の巾と波長との関係

\begin{tabular}{|c|c|c|c|c|c|c|}
\hline \multirow[b]{2}{*}{ Spalt } & \multicolumn{2}{|c|}{ Gelb-Spalt. } & \multicolumn{2}{|c|}{ Grün-Spelt } & \multicolumn{2}{|c|}{ Rote-Spalt. } \\
\hline & $\begin{array}{l}\text { Maximale } \\
\text { Wellenla- } \\
\text { nge }\end{array}$ & $\begin{array}{l}\text { Wellen } \\
\text { breite }\end{array}$ & $\begin{array}{l}\text { Maximale } \\
\text { Wellenla } \\
\text { nge }\end{array}$ & 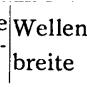 & $\begin{array}{l}\text { Maximale } \\
\text { Wellenla- } \\
\text { nge }\end{array}$ & $\begin{array}{l}\text { Wellen } \\
\text { breite }\end{array}$ \\
\hline 0 & $x$ & $x$ & 549.0 & 6.0 & $x$ & $x$ \\
\hline 20 & 591.0 & 8.0 & 548.1 & 6.0 & 654.0 & 4.0 \\
\hline 40 & 592.2 & 9.7 & 547.5 & 5.2 & 652.4 & 4.1 \\
\hline 60 & 593.0 & 9.3 & 546.9 & 4.8 & 650.4 & 5.1 \\
\hline 80 & 593.8 & 10.7 & $x$ & $x$ & 649.6 & 6.7 \\
\hline
\end{tabular}
(Anomaloscope II型 No. 10 (TAKATA) について)

(単位: $\mathrm{m} \mu$ )
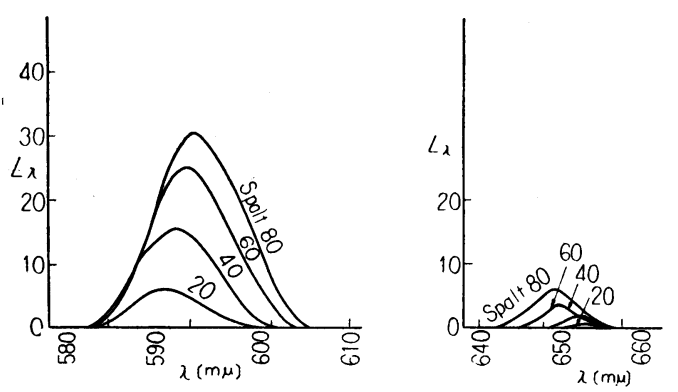

(A) (Gelb-Spalt Кついて (B) Rote-Spelt Кついて

第2図各細隙のゆと視野に現われる波長域および主 宰波長との関係

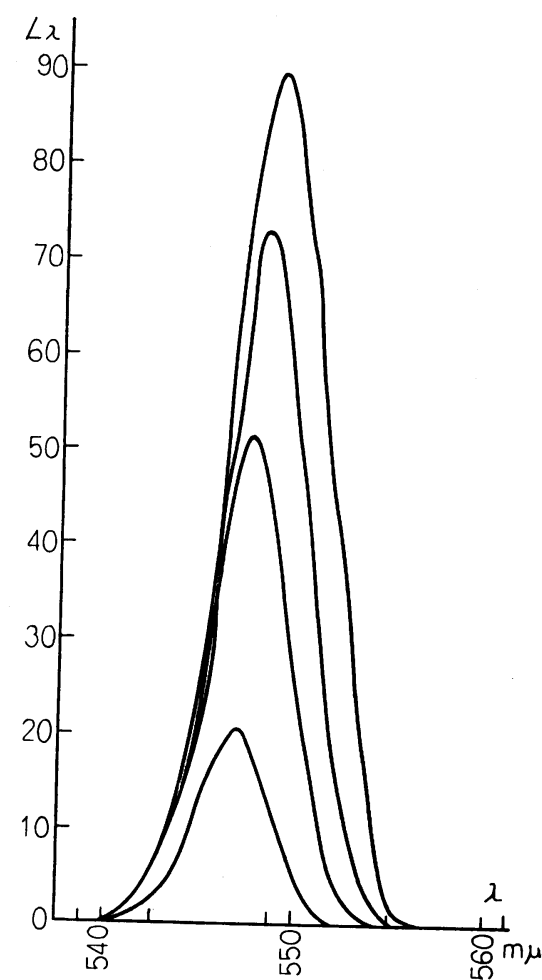

(C) Grün-Spalt kついて

第 2 表

\begin{tabular}{c|c|c}
\hline type.no. & $\mathrm{L}$. & $\mathrm{K}$. \\
\hline TAKATA (旧型) & $665.0 \mathrm{~m} \mu$ & $538.5 \mathrm{~m} \mu$ \\
" & 658.0 & 536.0 \\
" & 664.0 & 536.5 \\
" & 660.0 & 535.0 \\
" & 663.5 & 560.5 \\
" & 663.0 & 549.0 \\
" & 667.5 & 547.5 \\
TAKATA (新型) & 666.5 & 559.0 \\
" & 665.0 & 553.0 \\
" & 669.5 & 555.0 \\
" & 636.0 & 541.5 \\
" & 647.5 & 549.5 \\
Haensch-Schmidt & 660.5 & 535.5 \\
\hline
\end{tabular}

（註）単色スリットより $589.0 \mathrm{~m} \mu$ が出るよらに移動 据子度目を調整したをき，混色㹉子度目を80, お。 よび0としたときの混色スリットより出る色光の 波長をそれぞれL，Kとする。

アノマロスコープについて細隙より出る3檑の主辛波長 を測定した結果は第 2 表の如く器械によってかなりの差 が出ている. 従ってここに求めた理論式は 1 つ標準と なる值を与えることになるのであるが, 実際に種々のア ノマロスコープを用いて均等試験を行ってみた処では，

概ねこの理論值が容認あれることを知った。 事実器械に 
はそれぞれの癖があって完全に同じものの作られるはず はないのであるし，だからと云って購入したアノマロス コープについてその正常均等範囲を定め，また色弱者の 代表的均等值を求めることは一般臨床医家にとっては極 めてやっかいなことであり，この故にここに作った理論 式とそれに基く脳表の臨床的甞義があると思う。機械の 癖による均等範囲の誤差は, 理論式によって求められた 正常厸等範囲の限界にあるものに対して仮性同色表その 他の色営検査による検討を行うように努めることによっ て補うことが出来るものである。

そこで(7)式を用いて $\mathrm{Rn}=60$ のアノマロスコープの正

第 3 表 正常均等範囲の变化 $(R n=60$ の場合 $)$

\begin{tabular}{|c|c|c|c|c|c|c|c|c|c|}
\hline$a_{n}$ & 0 & 10 & 20 & 30 & 40 & 50 & 60 & 70 & 73 \\
\hline \multirow[t]{2}{*}{$a^{\prime}$} & 0 & 8.0 & 16.4 & 25.6 & 35.5 & 45.7 & 57 & 69.2 & 73 \\
\hline & 0 & 14.4 & 26.8 & 37.8 & 47.2 & 56.3 & 64 & 70.8 & 73 \\
\hline$a_{n}$ との & 0 & 2.0 & 3.6 & 4.2 & 4.5 & 4.3 & 3 & 0.8 & 0 \\
\hline 距 り\{ & 0 & 4.4 & 6.8 & 7.8 & 7.2 & 6.3 & 4 & 0.8 & 0 \\
\hline 巾 & 0 & 6.4 & 10.4 & 12.0 & 11.7 & 10.6 & 7 & 1.6 & 0 \\
\hline
\end{tabular}

第 4 表 正常均等範囲の変化 $(\mathrm{Rn}=400$ 場合 $)$

\begin{tabular}{|c|c|c|c|c|c|c|c|c|c|}
\hline$a_{n}$ & 0 & 10 & 20 & 30 & 40 & 50 & 60 & 70 & 73 \\
\hline \multirow{2}{*}{$a^{\prime}$} & 0 & 7.5 & 15.6 & 24.4 & 34 & 44.5 & 56.1 & 68.6 & 73 \\
\hline & 0 & 13.0 & 24.2 & 35.0 & 45 & 54.2 & 62.8 & 70.6 & 73 \\
\hline$a_{n}$ との $f$ & 0 & 2.5 & 4.4 & 5.6 & 6 & 4.5 & 3.9 & 1.4 & 0 \\
\hline 距 り\{ & 0 & 3.0 & 4.2 & 5.0 & 5 & 4.2 & 2.8 & 0.6 & 0 \\
\hline 巾 & 0 & 5.5 & 8.6 & 10.6 & 11 & 8.7 & 6.7 & 2.0 & 0 \\
\hline
\end{tabular}

常均等範囲を57〜64（Trendelenburg）とした場合，正 常レーレー均等の混色度目がそれぞれ $0 ， 10 ， 20,30$, 40，50，60，70，73にあるアノマロスコープを用いたと したときの正常均等範囲を計算したものが第 3 表，また $\mathrm{Rn}=40$ のアノマロスコープについて正常均等範囲を34 〜 45（市川）とした場合の前回同様の各種アノマロスコ ープにおける正常均等範囲を計算したものが第 4 表であ る.

表の臨床的意義について述べる前に，正常者の均等範 囲について簡単に触れておく必要がある. われわれの色 感は検査時の精神状態, 疲労の有無, 順応の状況等によ って影響をうけるものである。これらの諸点を完全に除 外し得たとしても尚, 季節の色感におよぼす影響が残る ことがすでに Dresler 等によって発見されている，即ち Richter は6月に maxmum, 1 月に minimum とな り, 両者の間に約 2.5 度目の均等差のあることを述べて いる. 従って 1 年間の検査成績の平均值にはこの seasonal variation が含まれていることになる。 また検查を 繰返し行った場合の成績の一致性について実験したI. Schmidt の報告では, 同一人についての11回連続検査
の場合, 有意の差の起る probability は1\%以下である が，その閒に練習効果がみられ，第 1 回と第 2 回の間に は有甞の差がないが，第 $1 ， 2$ 回とそれ以後の成績との は有意の钅がみられたという。即ち第3回以後間にには 数字の上で練習効果はないとし, 実験成績の正確を期す るためには初めの2回までの読みは除くべきであると述 べている，五觉正常者の均等範用を決めるにはこのよう な諸点を考虑に入れておくことが必要である．色觉の正 常範囲についてこれまでの諸家の述べているところを整 理すると，Engelking は1929 年 Amsterdam におけ る International Commission of Ophth. の席上で, $\mathrm{Rn}=60$ の場合混色ネヂの読み 57〜64（1.3〜0.65 A. Q.）の限界内で均等範国が 6 度目以内を正常とするこ とを述べている. Köllner は正常範囲に中央值 56〜64 $(\mathrm{Rn}=60)$ を用い，運用の際52〜66内で均等してこれ 以外の部分での均等がなければ正常範囲あるとし，この 範䎴内にあって色盲表検査に合格したものを正常色覚と している．その後 Trendelenburg は氏の論文の中に正 常者の均等範囲として， $\mathrm{Rn}=60$ の場合57〜64（1.3〜 0.65 A. Q.), $R n=40$ の場合 $35 \sim 48$ (1.3 0.63A.Q.) を採用しているが，正常範囲の protan 側（第 1 異常 側）の限界浾色哥（第1 色弱）の均等範囲之一部重 複していることを指搁している. I. Schmidt は前に 述べた如き検查時の練習效果と季節の影響を除きながら

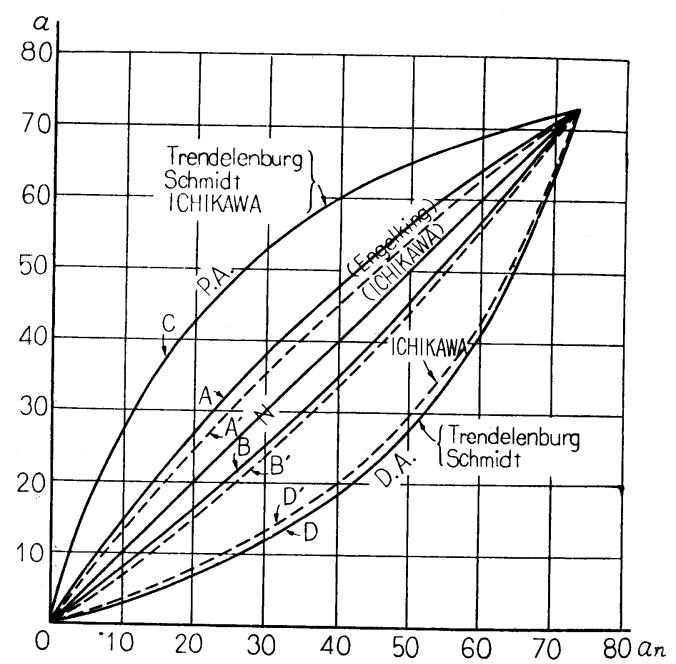

第 3 図或る值 $(R n)$ の正常レーレー均等値をもっア, マロスコープについて, 正常均等範囲および色 弱均等代表做を求める図。

統計的処理定行った絬果として，正常者の均等值分布域 に1.52 0.66 A. Q., 即ち約 35 50 $(\mathbf{R n}=42)$ の均等 值を挙げている. 私は災害医学的に色覚正常と判定した ものについて統計的に検討し, 正常者は $\mathrm{Rn}=40.5$ の場 合 1.49 〜 0,65 A.Q. の間にほとんどが分布している 結果を得た，これら諸氏の報告を一括した表（第 5 表） 
第 5 表の 1 正常均等及び異常均等の位置

\begin{tabular}{|c|c|c|c|c|c|c|}
\hline & & D A & & $\mathrm{N}$ & $\mathbf{P}$ & \\
\hline \multirow{3}{*}{$\begin{array}{l}\text { Trende- } \\
\text { lenburg }\end{array}$} & 均等値 & 18.5 & & 40.0 & \multirow{2}{*}{ gap } & 61 \\
\hline & A.:Q. & 3.55 & gap & 1.0 & & 0.27 \\
\hline & $\log$ A.Q. & 0.55 & gap & 0 & gap & -0.57 \\
\hline \multirow{3}{*}{ Schmidt } & 均等值 & 18.5 & 27.0 & 42.19 & 53.6 & 60.2 \\
\hline & A. Q. & 2.80 & 2.0 & 1.0 & 0.45 & 0.25 \\
\hline & $\log$ A.Q. & 0.55 & 0.3 & 0 & -0.35 & -0.6 \\
\hline \multirow{3}{*}{ Ichikawa } & 均等优 & 20.0 & 27.5 & 40.5 & 48 & 60.5 \\
\hline & A. $\mathbf{Q}$. & 3.17 & 2.0 & 1.0 & 0.63 & 0.25 \\
\hline & $\log$ A.Q. & 0.50 & 0.3 & 0 & -0.2 & -0.6 \\
\hline
\end{tabular}

第 5 表の 2 正常均等の巾

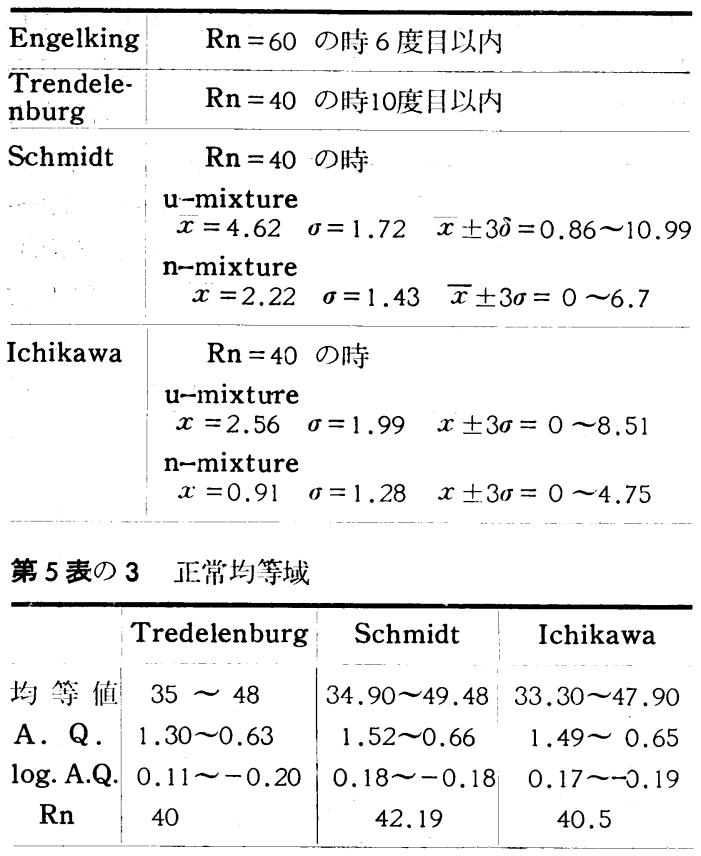

をみると，各氏の成績が概ねよく似たものであることが わかる. Rn=40 の場合の諸家の正常範囲については第 5 表の 3 および第 2 表と第 3 表から作図した第 3 四にみ られるように，市川が災害医学的に採用した正常範囲（ 統計的数值に更に災害医学的検討によって修正が加えら れたもの) は Trendelenburgや Schmidt のそれより 屯 deutan 側 (第 2 異常侧) にいくらかズレている. deutan 侧の 1.5 度目の差は臨床的にあまり差がある と云えないが, protan 側の 2.0 度目の差は色感の性質 の上からも少しく検討されねばならないものをもってい る，Trendelenburg による正常範囲の protan 側限 界附近は protanomaly の分布域と僅かであるが共有部 分をもっている.この其有部分を正常範囲から除外して みると protan 側の限界は46となって，私の提案した正
常範囲とあまり変らないことになる，正常範囲に属する 標本の分布の山と, protanomaly の分布の山との問に gap があるかどうかは，にわかに断定し難いが，TrE一 ndelenburg は両者は移行しているとし, Schmidt の 統計ではその間に gap が認められる。私の成績は Schmidt の絬果に近い。こうした点を考虑すると， Trendelenburg の data を規淮とした正常籁用よりも 私の正常範姍の方が災害医学的判定を下す上に実用に適 っているように思う。

前回と同様の過程によって赤色弱均等打よび縁色弱均 等の混色ネチ度月の代表値を計算したものが第 6 表と第 7 表であり，この成績を同じく第3図に plot した。こ

第 6 表 緑色弱均等値の変化

(A) $a^{\prime}=20(\mathrm{Rn}=40)($ Ichikawa) の值の変化

\begin{tabular}{c|c|c|c|c|c|c|c|c|c}
\hline & 0 & 10 & 20 & 30 & 40 & 50 & 60 & 70 & 73 \\
\hline 均等值 & 0 & 3.42 & 3.67 & 13.0 & 20 & 29.4 & 43.0 & 64.2 & 73 \\
A. Q. & - & 3.23 & 3.223 .23 & 2.21 & 3.23 & 3.22 & 3.6 & - \\
log A.R. & - & 0.51 & 0.51 & 0.51 & 0.51 & 0.51 & 0.50 & 0.50 & -
\end{tabular}

(B) $a^{\prime}=18.5(\mathrm{Rn}=40)$ (Trendeleburg and Schmidt) の值の変化

\begin{tabular}{c|c|c|c|c|c|c|c|c|c}
\hline & 0 & 10 & 20 & 30 & 40 & 50 & 60 & 70 & 73 \\
\hline 均等值 & 0 & 3.126 .97 & 11.95 & 18.5 & 27.6 & 41.363 .2 & 73 \\
A.Q. & - & 3.563 .58 & 3.61 & 3.56 & 3.58 & 3.553 .61 & - \\
log A.Q. & - & 0.550 .55 & 0.550 .55 & 0.55 & 0.550 .55 & - \\
\hline
\end{tabular}

第 7 表 赤色弱均等值の変化

$a^{\prime}=60(\mathrm{Rn}=40)$ (Trendelenburg and Schmidt) の值の変化

\begin{tabular}{l|l|l|l|l|l|l|l|l|l}
\hline & 0 & 10 & 20 & 30 & 40 & 50 & 60 & 70 & 73 \\
\hline 均等值 & 0 & 27.5 & 43.0 & 52.8 & 60 & 65.0 & 68.8 & 7.2 & 73 \\
A.Q. & -0.26 & 0.26 & 0.27 & 0.26 & 0.27 & 0.28 & 0.32 & - \\
log & $-0.58-0.58$ & -0.57 & -0.58 & -0.55 & -0.55 & -0.49 & - \\
A.Q. & - & & & & & & & &
\end{tabular}

の場合赤色弱均等の代表值は Trendelenburg， Schmi$\mathrm{dt}$ ，市川共に同じ值を得ているが，緑色弱均等の代表值 は Trendelenburg, および Schmidt が $\mathrm{Rn}=40$ の時 共に 18.5 附近であるのに比べて私の場合は 20 附近にあ る.これは私の取扱った症例では deutan は2.5A.Q. よ りも正常均等域側に分布する症例がかなり混っているた め，このように私の採用した緑色弱均等の代表值が正常 側にずれたものと思われるが，この附近は，同じ症例で も均等の巾の広いものが多く，比較均等值を採るなら混 色ネヂ度目の18.5とはほとえど同価値とみてよく,むし ろ deutan 側の代表值は Trendelenburg 等の值と市川 の值を共に含えだ巾のあるものとした方が実用に適って いると思う。このようにして作図された各表の data は 
第 3 図の上にラグビーのボール状の 4 っの曲線となって

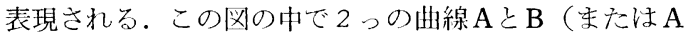

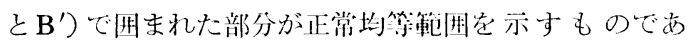
り，Cは赤色弱均等の代表值の軌跡， D（または $\mathrm{D}^{\prime}$ ） は緑色弱均等の代表值の軌跡である。このうち A， B， C，D注 Trendelenburg および Schmidt の成績を. A'， $\mathrm{B}^{\prime}, \mathrm{C} ， \mathrm{D}^{\prime}$ は市川の成䌙をそれぞれ基準にした曲線 である。

この忷の使用法は，侧えば正常レーレーの混色ネヂ度 円が50にあるアノマロスコープをもっていると与をと，

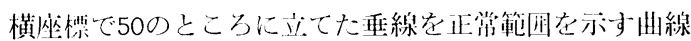
$\mathbf{A}^{\prime}$ 拉よび $\mathbf{B}^{\prime}$ が切る 2 点の縦座標54と440䦌が，このア

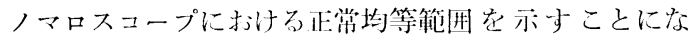

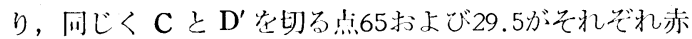

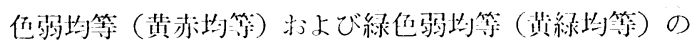
代表点を示すことになる。均等検査で正常レーレー均等 に近い值を得た埸合，それが54〜440中にあるか否かが 正常色觉判定の画要な資料となるし，胁他弱あるいは線 色弱が疑われる怔:例に遭遇したとき，それぞれ混色ネヂ 度目65あるいは29.5附近を目標に均等を求めると，比較 均等はこの附近に求められるであるうという見当がつ く.このようにして自分の用いるフノマロスコープにつ

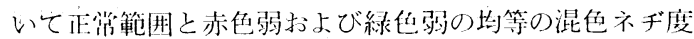
日を产せずして知ることが出来る。この場合図の A，B． C，Dの曲線を用いるか $\mathrm{A}^{\prime} ， \mathrm{~B}^{\prime}, \mathrm{C}, \mathrm{D}^{\prime}$ の曲線を用いる かは䏘い人の自由であるが，Dと $\mathrm{D}^{\prime}$ と沙点床的には ほとんど同価值であり，㡐述した如くむしろ Dと $\mathrm{D}^{\prime}$ に よって囲まれた巾のあるもの若えた方がよいように思

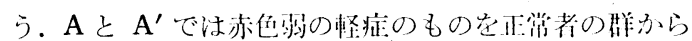
除くことの重要さから去って $\mathrm{A} よ り \mathrm{~A}^{\prime}$ の曲緗のうが怔 床的には優れていると思うが，この限界にあるものにつ いては仮性同任表その他の色覚検査法による吟味が必要

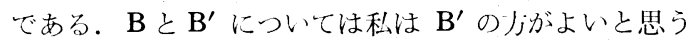
が， $B^{\prime}$ 附近の均等をもつものに対しても私は尣分検討 を加えることにしている。それは正常籁間にるものを アノマロスコープだけで直らに色営滘とすることは， 異型の色觉晎蒛安見逃与危険があるか心である。

尚ここに興怽ある事実は，第 3 ，倾 4 衣の混色市ヂ度 目の各 data を，それに対応する正常レーレーの度目に ついてA，Q．および $\log$ A. Q. を計算すると第8 表(A) (B)の如くすべてがほとんど同じA，Q.值を示している ことである。これはとりもなおさず A，Q．值が器械に無 関係に, 被検者の 3 種単色光に刘する主観的明度によっ て規定されるものであることの証明となった。色弱均等 においても第 5,6表ふら间じことが成立与るのが解る。 近藤上とは别な角度から A . Q . 值が光源や器械に無刘係 に成り立つことを䃌明したことになるのである。これは
第 8 表 正常均等域の A. Q. および $\log$. A.Q.

(A) $\mathrm{Rn}=60$ を標準としたとき

\begin{tabular}{l|l|l|l|l|l|l|l|l|l}
\hline$a_{n}$ & 0 & 10 & 20 & 30 & 40 & 50 & 60 & 70 & 73
\end{tabular}

A. Q. -1.387 [. $3901.3901 .393 \mid 1.3901 .3901 .490$ \begin{tabular}{l|l|l|l|l|l|l|l|l|} 
log & $-0.7330 .7440 .7120 .7550 .7550 .7520 .790-$
\end{tabular} (B) $\mathrm{Rn}=40$ を標準としたとき

\begin{tabular}{l|l|l|l|l|l|l|l|l|l}
\hline$a_{n}$ & 0 & 10 & 20 & 30 & 40 & 50 & 60 & 70 & 73
\end{tabular}

A. Q. -0.1370 .1430 .1430 .1440 .1430 .1430 .173 $\begin{aligned} & \log \\ & \text { A.Q. }\end{aligned}-0.13-0.13-0.13-0,12-0.12-0.12-0.10-$

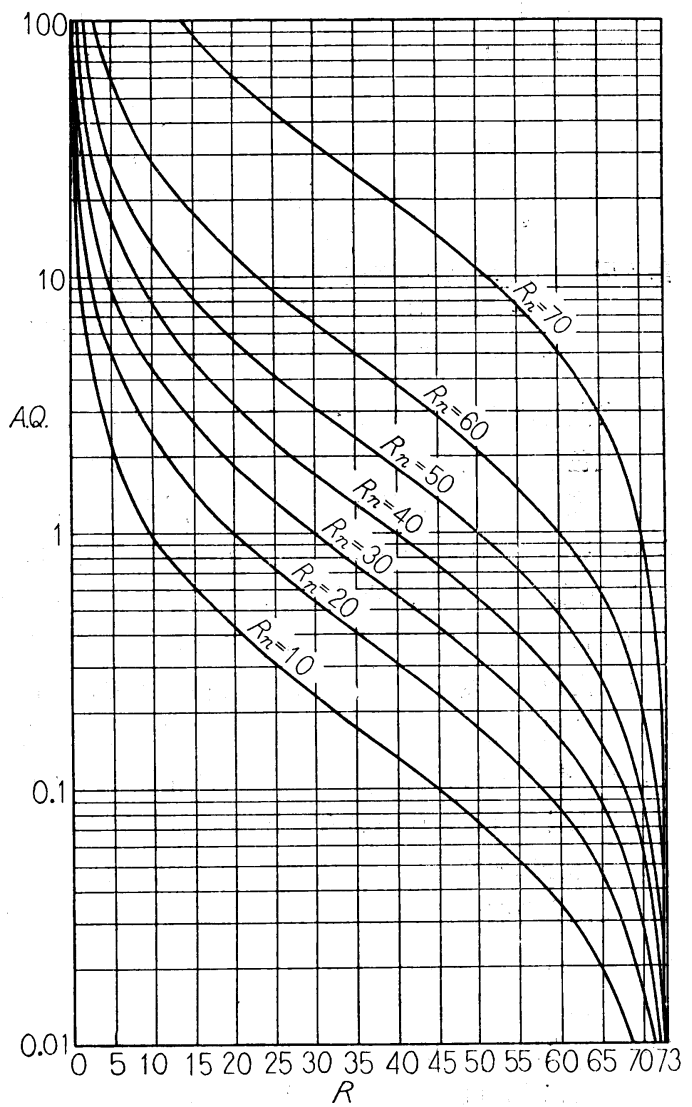

第 4 図 任意の正常均等値 $(\mathrm{Rn})$ をむつアノマロス コープに於ける混色ネヂ度目からの異常比 (A.Q.) 算出用曲線

また，第 3 図の内容を別の角度に立って作涧することを 可能ならしぬる。即ち A.Q.值表および $\log$ A. Q. 值表 岁第 4 ，第 5 四の如く作図した場合，第 5 図の横座標に 平行な直線 $\mathrm{C}, \mathrm{A}^{\prime}, \mathrm{B}^{\prime}, \mathrm{D}^{\prime}$ 注第3四の $\mathrm{C}, \mathrm{A}^{\prime}, \mathrm{B}^{\prime}, \mathrm{D}^{\prime}$ と全く同じ内谷虹もつものである. 即ち $\mathrm{A}^{\prime}$ と $\mathrm{B}^{\prime}$ の平

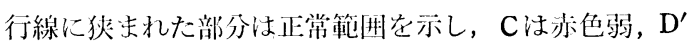
は緑色询の均均等度目の軌跡を示与直線である。S 字 


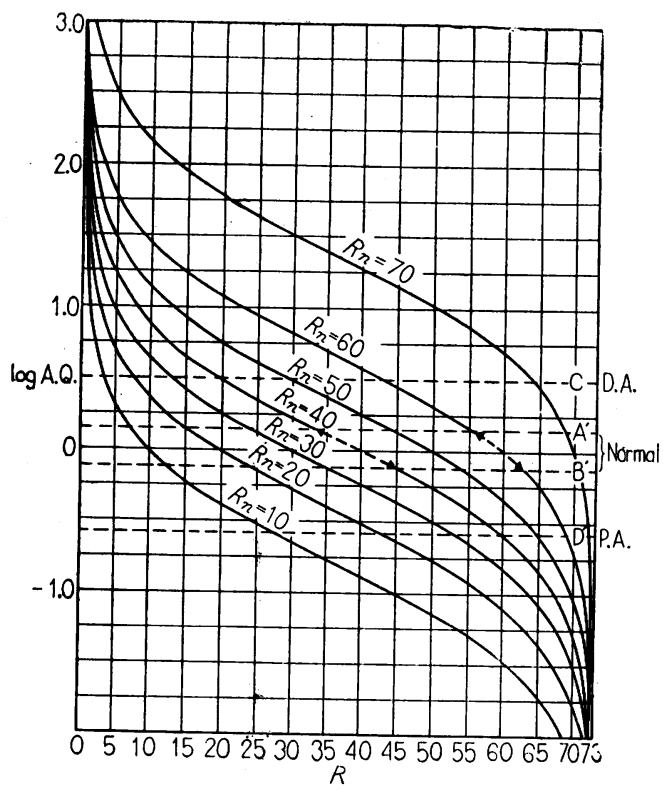

第 5 図任意の正常均等值 $(\mathrm{Rn})$ をるつアノマロス コープに於ける混色ネヂ度目からの異常比の 刘数值 ( $\log$ A.Q.) 算出用曲線

状の各明線はそれぞれの Rnのアノマロスコープについ て各混色ネヂ度目を巽常比で示したもので, 横座標は混 色ネヂ度目，縦座標は第4 図ではA.Q., 第 5 図では $\log$ A.Q. 去示すものである.この2つの悩の利用法はど ちらの表についても，使用しているアノマロスロープ の Rn についての曲線をとり挙げることによって, 検査 された混色ネヂ度目から直ちにその器械の正常レーレー に対する異常比および異常比の対数が縦軸によって読ま れ，その值が正常範囲にあるか否かは異常比に換算する までもなく， Rn の曲線が $\mathrm{A}^{\prime} ， \mathrm{~B}^{\prime}$ の2直線によって狭 まれる部分にあるかどうかで決められるし，同じように してまた赤色弱および緑色弱の均等部位も直ちに推测す ることが可能となるわけである。

以上私は必ずしも正常レーレーの Rn の值が60または 40にあると限らない，どのようなアノマロスコープを用 いた場合にも，直ちにその正常範囲と赤色弱および緑色

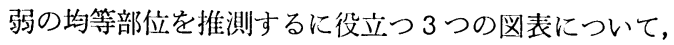
その成り立っと瀶床的意義について記述した。これによ ってアノマロスコープは使用する側にとって今までより 利用価值の多い検査器になったと思う。

\section{3. アノマロスコープによる色賞検查法に วいて}

次にアノマロスコープによる検査法のあらましについ て述ベる.アノマロスコープ操作の手順として私は Köllner, Schmidt, Monjé 等諸氏の検査法を参考にし
た次の如き方法を慣用している。

(1) あらかじめ正常レーレー均等を求めてからこれを 被検者に呈示し，単色ネヂ度目を少しく加減して均等が 成立するかどうかを確かめる，正常範囲内で均等の成立 するものは正常者か色盲 (二色型色覚) である。（両者 は色盲表により簡単に区別が出来る）.

(2) 色盲であることが推測された場合は混色ネヂ度目 0〜73について均等試験を行い, 全域において均等した 場合, 混色ネヂ度目73に対する単色ネヂ度目が小さいと きは第 1 色盲 (赤色盲), 此較的大きい場合は第 2 色盲 (緑色盲) であると診断される。

(3) 正常レーレーの附近で均等して正常か否か疑わし い場合は，均等值が正常範囲内にあって色盲表に異常が なければ正常，均等の中央值が正常範囲内にあっても均 等の巾がこれより外れているか，また均等の巾が異常に 広い場合は色盲表その他の色觉検査の成績を併せて正常 か否かを判定しなければならない。

(4) 正常レーレー均等での均等試験が成り立たない場 合は，正常者に均等している視野を被検者にみせて視野 の上半部の色調を閣い，赤味を帯びていると答えれば第 2 色弱（緑色弱），緑味を帯びていると答えれば第 1 色 弱（赤色弱）が推测される．このときは検查は第1色弱 あるいは第 2 色弱の平均均等部位を目標にして，それよ り混色ネヂ度日で0側，次いで73側から漸次均等試験を 行って色弱者の均等部位と均等範囲を決定する。

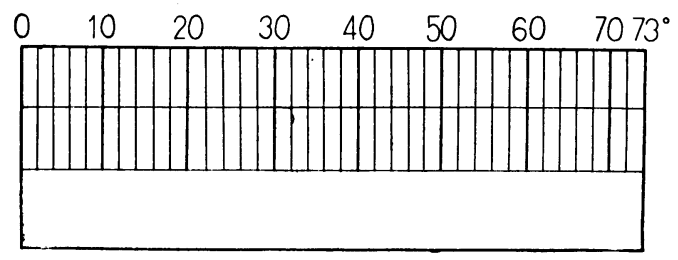

a) Einstellung des normaleu Untersuchers.

b) Einstellung des untersuchten.

c) Stellung der Gelbschraube am Ende der Gleichung.

(Deutsche Bundesbahn の Tauglichkeits vorschrift （1951）より記載)

第6図アノマロスコープイよる計測俌記載用 (記載例)

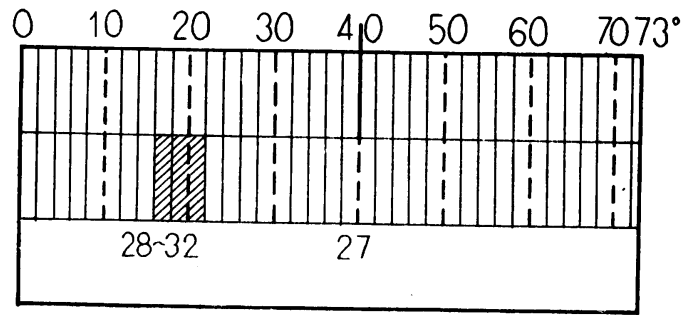

(Deuteranomalie) 


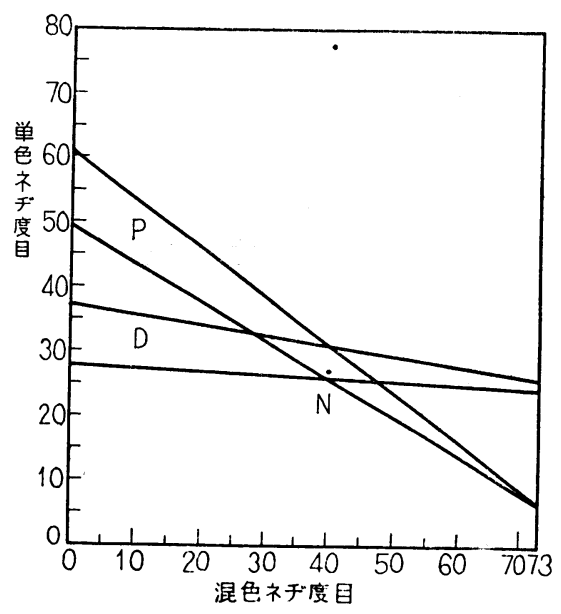

第7図 赤色盲と縁色盲の均等所見 (Anomaloscop II型 No. 10 TAKATA による)

以上が検査を行う順序であるが，均等部位を求める時 まづ比較均等を求めた後, 絶対均等を求めるのである が，前者でもせいぜい10,乃至15秒以内,後者では3 秒以 内の注視によって均等の有無を检査する必要がある。な お検査のたびに20秒位づつ明るい白壁や北側の空を見さ せて残像を消し，また疲労を除くようにしなければなら ない・このようにして検査した結果を記録するに Vierling の記載用式（第6図）があるが，これは一見して色 党異常の種類と程度を知ることが出来て便利である.

以上の如き検査の手順によって求められた均等值も， 検者がアノマロスコープに不馴れであったり，被検者が 色神衰弱をもっていたり，末た対比六進のつよい場合に はしばしば䛊まった均等を正しいものと䛊解して，その 為診断を誤るようなことがある。この場合第7 図の如き 四它，使用しているアノマロスコープについて作ってお くと，検査した成縝が正しいか否かの判断に資すること が出来るし，またある均等試験に際して混色ネヂ度目に 刘応する単任ネヂ度目を推测することが出来て, ことに 色弱者の絶対均等を求めるときに役立つものである. 良 ってこの四が色営異常の病型分類に役立つこともまた当 然である．この図の作成には第 1 色盲と第 2 色盲の患者 それぞれ 2 乃至 3 名があれば充分であるから, アノマロ スロープを使用する以上は自分のアノマロスロープにつ いてこの図を作成しておかね括ならない。第1色弱は第 1 色盲の均等值の軌跡上のどこかで均等するし, 第 2 色 弱はまた第 2 色盲の均等值の軌跡上のどこかで均等する のであるから.ある均等試験の結果が図中の PとDの領 域附近から離れた場所で均等したとすればその均等成績 は例外の塨合を除いて誤った均等結果であるということ に気付くはずである，なおこの図の中に前に述べた方法
で求めた正常範囲と，第 1 色弱および第 2 色弱の均等の 代表值を plot しておけば一層使い易い図となろう。前 に述べた各図は一般にどのアノマロスュープに対しても 直ちに用いることが山来るが，第7畄は备白が自分のア ノマロスコープについて作図しておかねばならないもの である。

アノマロスコープの検査については，以上の他視野の 広さや対比穴進の影響についてもその性質を熟知してい ないと，診断の結果を䛊るおそれがあるのであるが，こ れらについては别の機会に述べることにする。

\section{4. 結}

\section{論}

結論アノマロスコープの正常範囲を器械の個性に関係 なく表現し得る力法があれば便利であるうと考えて，理 論式を求め作図してみたのであるが，これと関連して赤 色弱, 緑色弱の均等部位についても同様の方法による作 四が可能になり,この結果は逆に異常比がアノマロスコ 一プの器械や光源に関係なく成立することの証明ともな った.かくして異常比（A.Q.）と混色ネヂ度目との関 係図の上に正常範囲拉よび赤, 緑色弱均等部位の軌跡を 記載することが出来るようになり，これらの諸図表はア ノマロスコープを新規に使用しようとする場合に利用価 值のあるものとなった. なおアノマロスコープを用いて 色覚検査を行う場合の検査順序や注意を要する諸点につ いても併せて凯載した。

譬篗に当り医長馬囟嘉範博士の御校閲に深謝致しま 广.

\section{主 要 交 献}

1) Vierling, F. : Zeitschr. f. Bahnarzte Nr. 11, (1933)

2) Schmidt, I. : Zeitschr. f. Bahnarzte Nr. 2, (1936)

3 ) 近藤忠雄: 日腿 43 ； 145 (1939)

4) Trendelenburg, W. : Kl. Mbl. Augenhk., 102 : 799 (1939)

5 ) Jaensch, P. A. : Ärztl. Dienst. DB., 15 Jahrgang, Feb. 21, (1954)

6) Schmidt, I. : J. O. S. A., $45: 514$, (1955)

$$
\text { (33-4-19 受付) }
$$

